\title{
Palaeoceanographic implications of abundance and mean proloculus diameter of benthic foraminiferal species Epistominella exigua in sub-surface sediments from distal Bay of Bengal fan
}

\author{
R Saraswat*, R Nigam and Lea Barreto \\ Micropaleontology Laboratory, National Institute of Oceanography, Dona Paula 403004 , Goa, India. \\ *e-mail: rajeev@darya.nio.org
}

\begin{abstract}
Temporal variation in abundance and mean proloculus diameter of the benthic foraminiferal species Epistominella exigua has been reconstructed over the last $\sim 50,000 \mathrm{yr}$ BP, from a core collected from the distal Bay of Bengal fan, to assess its potential application in palaeoceanographic reconstruction studies. The down-core variation shows significant change in abundance of E. exigua during the last $\sim 50,000 \mathrm{yr}$ BP. In view of the present day abundance of this species from areas with strong seasonal organic matter supply, we conclude that at $\sim 7, \sim 22, \sim 33$ and $\sim 46 \mathrm{kyr} \mathrm{BP}$, strong seasonality prevailed in the distal Bay of Bengal fan, probably indicating either strong or prolonged north-east monsoon or weakened south-west monsoon. For the first time, a strong correlation is observed in abundance and mean proloculus diameter of E. exigua. Based on coherent variation in mean proloculus diameter and abundance, it is postulated that mean proloculus diameter can also be used to infer increased seasonality in organic matter production, thus variation in strength or duration of monsoon. Thus, this study establishes that the down-core variation in the abundance and mean proloculus diameter of Epistominella exigua can be used to infer past climatic variations from the distal Bay of Bengal fan.
\end{abstract}

\section{Introduction}

Predicting climate is a difficult and delicate task. It depends on how well we know the past climate. In the absence of instrumental records, proxy records from natural archives such as lakes and ocean sediments, ice cores, tree rings, corals, etc. are used. Marine sediments are an important source for studying past climatic changes. The climatic history preserved in marine sediments can unfold mysteries by using various proxies. In order to have a comprehensive and compatible reconstruction of climate, different parameters of marine microfossils are used.

Among various microfossils, characteristics of foraminifera, a majority thriving in marine environments and very sensitive to climatic changes, have been used as a reliable proxy to decipher palaeoenvironment conditions and other related phenomenon.

Extreme sensitivity of foraminifera and specific response to a specific set of physico-chemical conditions has led to their extensive application in palaeoclimatic studies. Since planktic foraminifera are surface seawater dwellers, they reflect changes in surface seawater, while benthic foraminifera especially from the deeper regions of oceans, are reliable representatives of changing bottom water conditions. Variation in bottom water conditions includes variation in dissolved oxygen and carbondioxide content, regulated by the amount of organic matter flux which varies from seasonal to annual scale, and changes in source water that varies over longer time scales of thousands of years.

Keywords. Epistominella exigua; abundance; mean proloculus diameter; Bengal fan; monsoon. 


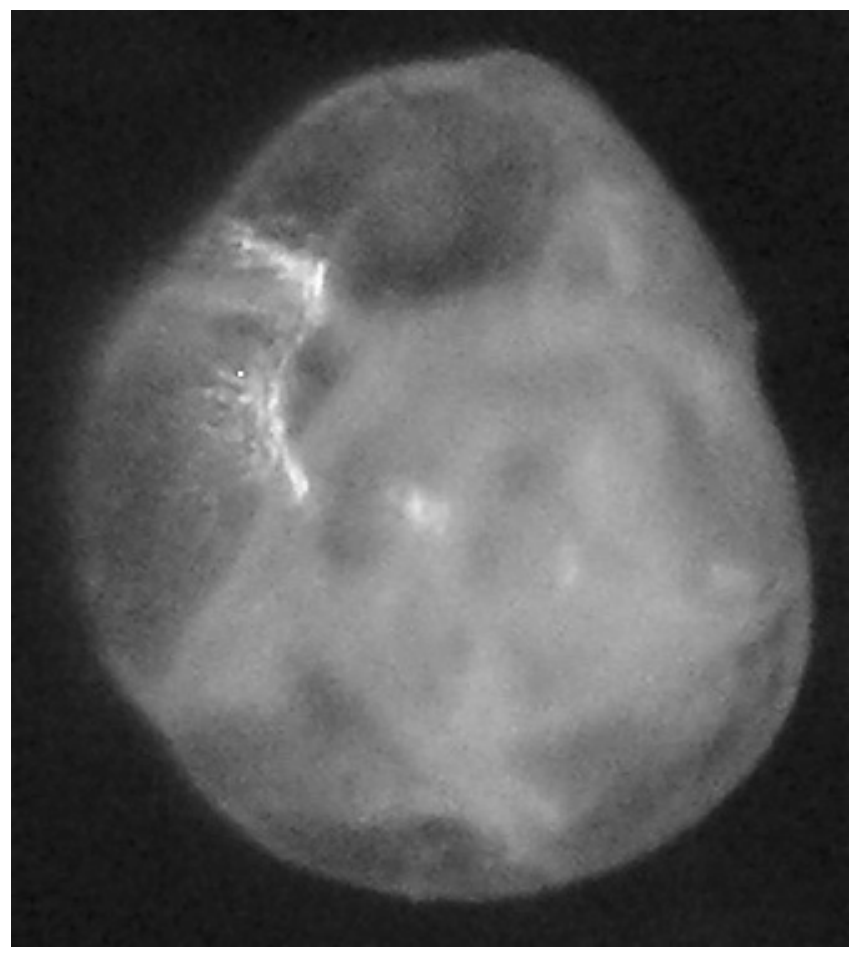

Figure 1. Epistominella exigua.

Through this study we explore the potential application of temporal variation in the abundance and mean proloculus size of the benthic foraminiferal species Epistominella exigua from the distal Bay of Bengal fan sediments, to infer past bottom water conditions (figure 1 ).

\section{Epistominella exigua}

Epistominella exigua is a trochospirally coiled, calcareous species with smooth surface (Murray 1991). E. exigua is a sporadically epifaunal detritivore, usually associated with a pulsed supply of phytodetritus and elevated oxygen concentrations (Gooday 1993; Mackensen et al 1995; Schmiedl et al 1997; Nees and Struck 1999; Gupta and Thomas 2003). Abundance of thin-walled Epistominella exigua has been noted to indicate slightly less carbonate-corrosive conditions. The increased abundance of E. exigua has also been correlated with seasonal pulses of food supply (Gooday 1993). According to Fontanier et al (2003), the taxa Epistominella exigua, Reophax guttiferus, Bolivina spathulata, Cassidulina carinata and Nuttallides pusillus appear to respond to labile organic matter input. Boltovskoy and Lena (1969) showed that in eutrophic shallow water (few meters water depth) environments, E. exigua has a short reproductive cycle (about one month) and reproduces throughout the year. Gupta (1997), Gupta and Thomas (2003) and Singh and Gupta (2004), reported
E. exigua from Indian waters and applied the variation in abundance of this species for palaeoclimatic reconstruction studies. Epistominella exigua like many other benthic foraminiferal species exhibits dimorphism, i.e., microspheric (with small proloculus) and megalospheric (with large proloculus) forms. Though, in nature, the microspheric and megalospheric forms of various benthic foraminifers are always present, their relative abundance is reportedly affected by physico-chemical conditions, thus their relative abundance is utilized to study palaeoclimate (Nigam 1986). However, distinction between dimorphic forms is not always possible (Nigam and Rao 1987; Nigam and Khare 1992). In such cases, instead of ratio of dimorphic forms, mean proloculus diameter will be more useful as it will have a direct relationship with the ratio of microspheric to megalospheric forms, because higher ratio will normally be reflected in lower mean size of the proloculus (Nigam and Rao 1987). This has successfully been used by Nigam (1988).

\section{Physiography of the study area}

The study area is currently influenced by seasonally reversing surface currents (summer and winter monsoon currents) resulting from the periodic monsoonal wind blowing from southwest during summer (June-September) and from the northeast in winter (November-February) (Shankar et al 2002). Eighty per cent of precipitation falls during the southwest monsoon (Cullen 1981). Summer monsoon is the dominant feature that brings about large-scale changes in circulation and heat content distribution in the Bay of Bengal. During this season the Bay of Bengal receives excessive precipitation and fresh water runoff from several major and minor rivers all along the east coast of India. The bay also receives a good amount of precipitation during winter monsoon, but precipitation as well as river runoff is comparatively low during winter monsoon. Total river runoff during the summer monsoon amounts to $943.206 \times 10^{9} \mathrm{~m}^{3}$, while that during winter monsoon is $103.767 \times 10^{9} \mathrm{~m}^{3}$ (Varkey et al 1996).

\section{Materials and methods}

The present study is based on 50 samples from the top $100 \mathrm{~cm}$ section of a gravity core collected during the 157th cruise of ORV Sagar Kanya under the Department of Ocean Development (DOD) funded project. This core is located at $4.6^{\circ} \mathrm{N}$ latitude and $85.4^{\circ}$ E longitude and a water depth of $3439 \mathrm{~m}$ (figure 2). 


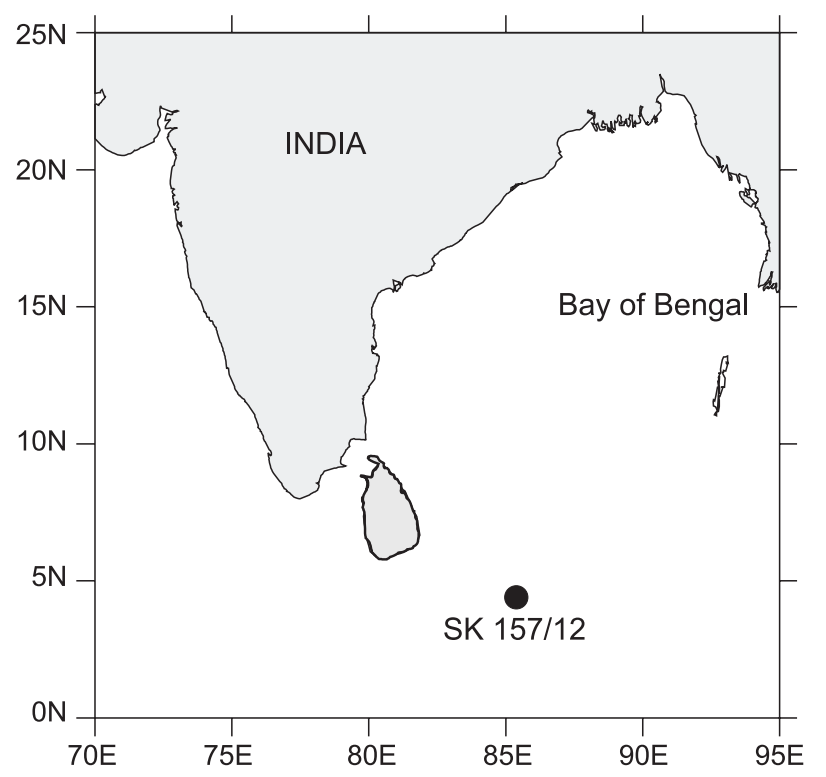

Figure 2. Core location.

Five to ten grams of sediment from each sample was dried overnight at $45^{\circ} \mathrm{C}$. Each dried sample was weighed and soaked in distilled water and subsequently treated with $5-10 \mathrm{ml}$ of $10 \%$ sodium hexametaphosphate to dissociate the clay particles followed by $5 \mathrm{ml}$ of $10 \%$ hydrogen peroxide to oxidize the organic matter, if present. The treated samples were wet sieved through a $63 \mu \mathrm{m}$ (250 mesh) size sieve. The sand residue retained over the sieve was dried (at $45^{\circ} \mathrm{C}$ ) to get the sand fraction weight.

From an appropriate (varying from sample to sample, $\sim 0.2500-0.0400 \mathrm{~g})$ aliquot of sand fraction, $\sim 300$ specimens of benthic foraminifera were picked, mounted on micropalaeontological slides and percentages of the individual species were calculated. From these picked benthic foraminifera, specimens of E. exigua were sorted. The size of the proloculus for each specimen was measured by using an Olympus Stereozoom microscope 'SZX12', with a maximum magnification of $180 \times$ and precision of $\pm 3 \mu \mathrm{m}$, by keeping the specimen in dorsal view. A total of 872 E. exigua specimens were picked from 50 samples, for the present study and each data point is an average of $\sim 18$ specimens.

In order to smoothen the down-core variation of all parameters to avoid minor variations, a twopoint running average was calculated and plotted against the depth. However, higher level averaging (3 or 5 point) was avoided in view of the coarse resolution of the core and to avoid attenuation of important events.

The age for the top $100 \mathrm{~cm}$ of the core, studied for the present work is based on two monospecific planktic foraminifer (Globorotalia

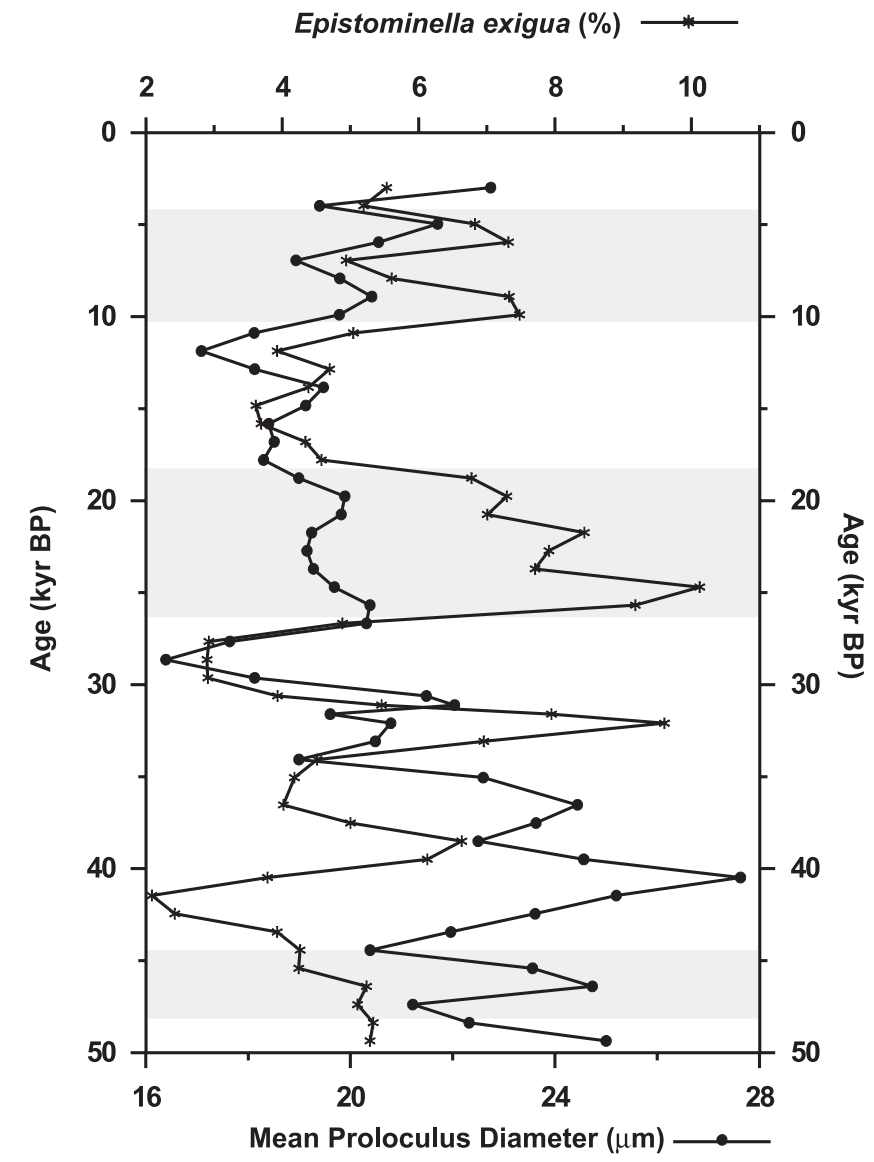

Figure 3. Down-core variation of abundance and mean proloculus diameter of E. exigua.

menardii) Accelerator Mass Spectrometer radiocarbon dates at $02-04 \mathrm{~cm}$ and $48-50 \mathrm{~cm}$ interval $(3700 \pm 25$ and $22170 \pm 130 \mathrm{yr}$ BP respectively), calibrated by using Calib Rev 5.0.1 software (Stuiver et al 2005) and corrected for $\Delta R$ (difference between the regional and global marine ${ }^{14} \mathrm{C}$ age) by using the values of Dutta et al (2001).

\section{Results}

The relative abundance of Epistominella exigua is comparatively high towards the bottom of the core but decreases sharply till $\sim 42 \mathrm{kyr}$ BP (figure 3). From $\sim 42 \mathrm{kyr}$ BP upwards, the abundance shows a fluctuating trend, with an increase till $\sim 33 \mathrm{kyr}$ BP. Above $\sim 33 \mathrm{kyr}$ BP, the abundance decreases sharply till $\sim 27 \mathrm{kyr}$ BP to increase again till $\sim 25 \mathrm{kyr}$ BP. From $\sim 25 \mathrm{kyr}$ BP upwards, the abundance decreases gradually till $\sim 18 \mathrm{kyr} \mathrm{BP}$ and remains comparatively low till $\sim 12 \mathrm{kyr} B P$. The relative abundance of E. exigua remains comparatively high $(>\sim 5 \%)$ throughout the upper portion of the core till $\sim 12$ cal kyr BP and in the top sample the relative abundance of $E$. exigua is reported to be $\sim 5 \%$. 
Down-core variation of mean proloculus diameter of E. exigua, in general, closely follows that of $E$. exigua relative abundance, except for a brief period ( 35-37 kyr BP) towards the lower part of the core (figure 3 ). The mean proloculus diameter is comparatively larger towards the bottom of the core section and remains high till $\sim 32 \mathrm{kyr} B P$, with a fluctuating trend. Above $\sim 32 \mathrm{kyr} \mathrm{BP}$, the mean proloculus diameter decreases till $\sim 28 \mathrm{kyr}$ BP. From $\sim 28 \mathrm{kyr} B P$ onwards the mean proloculus diameter increases and remains comparatively large till $\sim 18 \mathrm{kyr} \mathrm{BP}$. Above $\sim 18 \mathrm{kyr} \mathrm{BP}$, the mean proloculus diameter decreases slightly and remains smaller till $\sim 10$ kyr BP. From $\sim 10$ kyr BP upwards, the mean proloculus diameter remains comparatively large till the top of the core. The lowest mean proloculus diameter $(\sim 16 \mu \mathrm{m})$ is reported at $\sim 28 \mathrm{kyr} \mathrm{BP}$ while the maximum $(\sim 27 \mu \mathrm{m})$ is reported at $\sim 40 \mathrm{kyr} \mathrm{BP}$. Though the general down-core variation trend of both abundance and mean proloculus diameter of E. exigua is similar, as evident from the figure, the point-topoint correlation value is very low, probably due to slightly incoherent and non-linear response of both abundance and mean proloculus diameter of $E$. exigua, to changing physico-chemical parameters.

\section{Discussion}

Previously, Epistominella exigua has been reported to be a sporadically epifaunal detritivore, usually associated with a pulsed supply of phytodetritus (Gooday 1993, 1994; Mackensen et al 1995; Schmiedl et al 1997). Gupta and Thomas (2003) grouped E. exigua along with species that indicated cool, strongly pulsed, low-to-intermediate flux and highly seasonal environments and applied this to infer palaeomonsoonal variations in the equatorial Indian Ocean region.

Based on the present day abundance of this species from areas with high seasonal organic food supply, it is inferred that similar conditions prevailed in the distal Bay of Bengal fan at $\sim 7, \sim 22$ and $\sim 33 \mathrm{kyr} \mathrm{BP}$, and $\sim 46 \mathrm{kyr} \mathrm{BP}$ as the abundance of $E$. exigua shows prominent peaks at these times. Seasonal productivity variations in the Bay of Bengal fan are strongly influenced by seasonally reversing monsoon winds as well as associated eddies, precipitation and fresh water discharge (Prasannakumar et al 2004). Though upwelling along the western boundary of Bay of Bengal has been reported during the southwest monsoon (Shetye et al 1991), widespread low salinity water capping and cloud cover inhibits increased productivity, usually associated with upwelling zones, especially in northern Bay of Bengal (Gomes et al 2000). However, comparatively low fresh water influx and high wind strength results in thickening of mixed layer during the southwest monsoon season in the southern Bay of Bengal fan, leading to increased productivity during July to September (Unger et al 2003). Therefore, decrease in the strength or duration of southwest monsoon will result in decreased wind strength, leading to low productivity and thus increased seasonality in organic matter production. Similar conditions will also prevail if the strength or duration of the northeast monsoon increases. Thus increased seasonal pulsed organic matter production may be associated with increased (decreased) strength/duration of northeast (southwest) monsoon. Similar observations about the weakened southwest and intensified northeast monsoon during cold periods were also made by Duplessy (1982), Cullen (1981) and Fontugne and Duplessy (1986).

Morphological variations of tests, as well as the variation in the distribution of benthic foraminifera have previously been applied to infer past climatic variations and evolutionary aspects of foraminifera (Nigam and Khare 1999; Saraswati 2003) from the west coast of India. Nigam and Khare (1992) applied the mean proloculus size of benthic foraminiferal species Rotalidium annectens, to infer past salinity variations based on cores collected from nearshore areas. Nigam and Rao (1989) also noted that proloculus size in Cavarotalia annectens is strongly correlated with the coiling direction ratio, with forms having smaller proloculus preferring dextral coiling. The high percentages of E. exigua together with mean proloculus diameter enabled us to infer that during favourable conditions marked by increased seasonal organic matter supply, the mean proloculus size of E. exigua specimens increases. Since mean proloculus diameter is suggestive of the mode of reproduction, simultaneous variation in mean proloculus diameter and abundance possibly indicates variation in mode of reproduction as per environmental conditions. Further work is in progress to confirm the hypothesis and the results will be published in due course.

\section{Conclusions}

Based on the present study from distal Bay of Bengal fan, we conclude that relative abundance of E. exigua has varied considerably over the last $\sim 50,000 \mathrm{yr}$ BP. The mean proloculus diameter has also been found to vary in accordance with the variation in abundance of E. exigua. In view of the present day abundance of this species from areas with strong seasonal organic matter supply, it is concluded that increased down-core abundance of this species at $\sim 7 \mathrm{kyr} \mathrm{BP}, \sim 22 \mathrm{kyr} \mathrm{BP}$ and 
$\sim 33 \mathrm{kyr} \mathrm{BP}$, and $\sim 46 \mathrm{kyr} \mathrm{BP}$ indicates that similar conditions prevailed in the distal Bay of Bengal fan. Strong seasonality in organic matter supply corresponds with increased intensity or duration of northeast monsoon or decreased intensity and duration of southwest monsoon. Thus during these intervals, probably northeast (southwest) monsoon was comparatively more (less) intense or the duration of north-east (southwest) monsoon was more (less). This study establishes that down-core variation in relative abundance and mean proloculus diameter of Epistominella exigua can probably be used to infer past climatic variations on various time scales.

\section{Acknowledgements}

Authors are thankful to Dr. S R Shetye, Director, National Institute of Oceanography, Goa, for permission to publish this work. The Department of Ocean Development is thankfully acknowledged for financial support. Authors are grateful to Drs. Bruce W Hayward and Anil K Gupta for critical comments and suggestions to improve the manuscript. One of the authors (RS) thankfully acknowledges the Council of Scientific and Industrial Research, New Delhi and UGC-DAAD for financial support in the form of a Senior Research Fellowship and short term DAAD Fellowship, respectively. Authors are thankful to Prof. A Mackensen of Alfred-Wegener Institute for Polar and Marine Research, for the AMS radiocarbon dates.

\section{References}

Boltovskoy E and Lena H 1969 Seasonal occurrences, standing crop and production in benthic foraminifera of Puerto Deseado; Contr. Cushman Found. Foram Res. 3 $87-95$.

Cullen J L 1981 Microfossil evidence for changing salinity patterns in the Bay of Bengal over the last 20,000 years; Paleogeogr. Paleoclimatol. Paleoecol. 35 315-356.

Duplessy J C 1982 Glacial to interglacial contrasts in the northern Indian Ocean; Nature 295 494-498.

Dutta K, Bhushan R and Somayajulu B L K $2001 \Delta$ R correction values for the Northern Indian Ocean; Radiocarbon 43 483-488.

Fontanier C, Jorissen F J, Chaillou G, David C, Anschutz P and Lafon V 2003 Seasonal and interannual variability of benthic foraminiferal faunas at $550 \mathrm{~m}$ depth in the Bay of Biscay; Deep-Sea Res. 50 457-494.

Fontugne M R and Duplessy J C 1986 Variations of the monsoon regime during the upper Quaternary: evidence from carbon isotopic record of organic matter in the north Indian Ocean sediments; Paleogeogr. Paleoclimatol. Paleoecol. 56 69-88.

Gomes H R, Goes J I and Saino T 2000 Influence of physical processes and freshwater discharge on the seasonality of phytoplankton regime in the Bay of Bengal; Cont. Shelf Res. 20 313-330.
Gooday A J 1993 Deep-sea benthic foraminiferal species which exploit phytodetritus: characteristic features and controls on distribution; Mar. Micropaleontol. 22 187-205.

Gooday A J 1994 The biology of deep-sea foraminifera: a review of some advances and their significance in paleoecology; Palaios 9 14-31.

Gupta A K 1997 Paleoceanographic and paleoclimatic history of the Somali Basin during the PliocenePleistocene: multivariate analyses of benthic foraminifera from DSDP Site 241 (Leg 25); J. Foraminiferal Res. 27 196-208.

Gupta A K and Thomas E 2003 Initiation of Northern Hemisphere glaciation and strengthening of the northeast Indian monsoon: Ocean Drilling Program Site 758, eastern equatorial Indian Ocean; Geology 31 $47-50$.

Mackensen A, Schmiedl D K, Harloff J and Giese M 1995 Deep-sea foraminifera in the South Atlantic Ocean: Ecology and assemblage generation; Mar. Micropaleontol. 41 342-358.

Murray J W 1991 Ecology and Paleoecology of Benthic Foraminifera. John Wiley, New York and Longman Scientific and Technical, Harlow, UK 1-397.

Nees S and Struck U 1999 Benthic foraminiferal response to major paloeceanographic changes. In: Reconstructing Ocean History: A Window into the Future, Abrantes F, Mix A (eds), Kluwer Academic/Plenum Publishers, pp. 195-216.

Nigam R 1986 Dimorphic forms of Recent foraminifera: an additional tool in paleoclimatic studies; Palaeogeogr. Palaeoclimatol. Palaeoecol. 53 239-244.

Nigam R 1988 Reproductive behaviour of benthic foraminifera: a key to paleoclimate; Proc. Indian Natl. Sci. Acad. 54 585-594.

Nigam R and Khare N 1992 The reciprocity between coiling direction and dimorphic reproduction in benthic foraminifera; J. Micropalaeontol. 11 221-228.

Nigam R and Khare N 1999 Spatial and temporal distribution of foraminifera in sediments off the central west coast of India and use of their test morphologies for the reconstruction of paleomonsoonal precipitation; J. Micropaleontol. 45 285-303.

Nigam R and Rao A S 1987 Proloculus size variation in Recent benthic foraminifera: implications for palaeoclimatic studies; Est. Coastal Shelf Sci. 4 649-655.

Nigam R and Rao A S 1989 The intriguing relationship between coiling direction and reproductive mode in benthic foraminifera; J. Paleontol. Soc. India 34 $1-6$.

Prasannakumar S, Nuncio M, Narvekar J, Kumar A, Sardessai S, DeSouza S N, Gauns M, Ramaiah N and Madhupratap M 2004 Are eddies nature's trigger to enhance biological productivity in the Bay of Bengal?; Geophys. Res. Lett. 31 1-5.

Saraswati P K 2003 Progress in the morphometrics of foraminifera; Gond. Geol. Magz. 6 11-18.

Schmiedl G, Mackensen A and Muller P J 1997 Recent benthic foraminifera from the eastern South Atlantic Ocean; dependence on food supply and water masses; Mar. Micropaleontol. 32 249-287.

Shankar D, Vinayachandran P N and Unnikrishnan A S 2002 The monsoon currents in the north Indian Ocean; Progr. Oceanogr. 52 63-120.

Shetye S R, Shenoi S S C, Gouveia A D, Michael G S, Sundar D and Nampoothiri G 1991 Wind-driven coastal upwelling along the western boundary of the Bay of Bengal during the southwest monsoon; Cont. Shelf Res. 11 1397-1408. 
Singh R K and Gupta A K 2004 Late Oligocene-Miocene evolution of the southeastern Indian Ocean: Results from deep-sea Benthic foraminifera (ODP Site 757); Mar. Micropaleontol. 51 153-170.

Stuiver M, Reimer P J and Reimer R W 2005 CALIB 5.0; [WWW program and documentation].

Unger D, Ittekkot V, Schafer P, Tiemann J and Reschke S 2003 Seasonality and interannual variability of particle fluxes to the deep Bay of Bengal: influence of riverine input and oceanographic processes; Deep-Sea Res. 50 897-923.

Varkey M J, Murty V S N and Suryanarayana A 1996 Physical oceanography of the Bay of Bengal and Andaman Sea; In: Oceanography and Marine Biology: an Annual Review, A D Ansell, R N Gibson and M Barnes (eds) UCL Press. 34 1-70.

MS received 26 April 2005; revised 11 July 2005; accepted 21 July 2005 